\title{
HLA system and side effects of gold salts and D-penicillamine treatment of rheumatoid arthritis
}

\author{
T. BARDIN ${ }^{1}$ A. DRYLL,${ }^{1}$ N. DEBEYRE,${ }^{1}$ A. RYCKEWAERT $,{ }^{1} L . L E G R A N D,{ }^{2}$ \\ A. MARCELLI, ${ }^{2}$ AND J. DAUSSET ${ }^{2}$
}

From the ${ }^{1}$ Clinique de Rhumatologie, Centre Viggo Petersen, Université Paris VII, Faculté de Médecine Lariboisière, 6 rue Guy Patin, 75010 Paris; and ${ }^{2}$ Unité INSERM U 93, Hôpital St Louis, Paris, France

SUMMARY Among 67 patients with rheumatoid arthritis treated with gold salts (aurothiopropanol sulphonate) a significant correlation $\left(\mathrm{p}<10^{-2}\right)$ was noted between gold toxic reactions, whatever their type, and the HLA antigens A1, B8, Cw7, and DR3. Forty-two patients were genotyped, and a correlation was observed between gold side effects and the haplotype A1 Cw7 B8 DR3 (p<10 ${ }^{-2}$, $R R=8 \cdot 0$ ). In addition 3 out of 4 cases of renal intolerance to $D$-penicillamine were observed in patients possessing the Cw7 B8 DR3 haplotype.

Adverse reactions during therapy with gold salts and D-penicillamine, which represent one of the limiting factors in the use of these drugs for rheumatoid arthritis (RA), may be associated to the major histocompatibility complex (MHC). ${ }^{1}$ The present paper provides further evidence in favour of such a relationship by demonstrating a correlation between gold salt intolerance and the A1 Cw7 B8 DR3 haplotype and a possible association between renal side effects of D-penicillamine and the Cw7 B8 DR3 haplotype.

\section{Materials and methods}

Sixty-seven Caucasian patients (51 females, 16 males) with a mean age of $56 \cdot 16$ years (range: $29-79$ ) all living in the Paris area were the subjects of this study. All patients suffered from seropositive, classical adult RA following the criteria of the American Rheumatism Association. ${ }^{2}$ At the time of performing this study the mean duration from onset of illness was $15 \cdot 64 \pm 12 \cdot 2$ years (range 1.5-48). All patients had been treated with sodium aurothiopropanol sulphonate, and 29 had also received D-penicillamine.

All cases were reviewed to evaluate tolerance to this treatment and to determine the HLA phenotype of each patient. In addition, a familial investigation was conducted in 42 cases. The patients were tested for 49 alleles of the 4 HLA loci. HLA A, B, and C groups were determined by the microlymphocytotoxicity method $^{3}$ using peripheral blood. The DR

Accepted for publication 16 October 1981.

Correspondence to Dr T. Bardin, Centre Viggo Petersen, 6 rue Guy Patin, 75010 Paris, France. specificities were determined by the standard technique described by Legrand and Dausset. ${ }^{4}$

\section{STATISTICAL METHODS}

Antigenic and haplotypic frequencies were determined by direct counting. The level of significance of the association between gold intolerance and HLA antigens or haplotypes was evaluated by the chisquare test. The relative risk was calculated by the classical Woolf method. ${ }^{5}$ Gene frequency was calculated by the Bernstein formula, and the Bengtsson and Thomson formula ${ }^{6}$ was used to evaluate the degree of association between a possible gene predisposing to gold salt reactions and the HLA genes:

$$
\delta=\text { FAD }- \text { FAP } / 1-\text { FAP }
$$

where $F A D$ is the gene frequency in the patients who do not tolerate gold salts and FAP is the frequency in the population which does tolerate gold salts.

\section{Results}

The patients studied here seemed to be immunogenetically comparable to the overall population of seropositive RA cases already studied at the Centre Viggo Petersen. ${ }^{7}$ In particular, the gene frequency of DR4 in these 67 cases of RA was 0.38 , which is very similar to that already established $(0 \cdot 42)$.

GOLD SALT INTOLERANCE

Among the 67 patients treated 30 cases of intolerance to sodium aurothiopropanol sulphonate were recorded: 9 proteinuria, 16 cutaneous intolerances, 3 stomatitis, 1 leucopenia, 1 hyperthermia. 
The statistical analysis showed a correlation between gold salt intolerance and 4 HLA antigens (Table 1). The antigen distribution does not differ significantly with respect to the type of reaction. Hence the various modes of intolerance can be grouped into a single class.

Among the 42 patients for whom it was possible to determine the genotype from the familial investigation 21 showed poor tolerance to gold salts. These adverse reactions were: 6 proteinuria, 2 stomatitis, 11 cutaneous reactions, 1 leucopenia, 1 febrile reaction. In these patients a significant correlation was noted between gold salt intolerance-of whatever type-and the haplotype A1 Cw7 B8 DR3 (Table 2).

The use of the Bengtsson and Thomson formula ${ }^{6}$ for calculating the degree of association between the postulated predisposing gene and the HLA alleles showed that the degree of association was of the same order whatever the haplotype segment analysed (Table 3).

Table 1 HLA antigen distribution in RA patients with and without gold side effects

\begin{tabular}{|c|c|c|c|c|}
\hline $\begin{array}{l}\text { HLA } \\
\text { antigens }\end{array}$ & $\begin{array}{l}\text { Patients with } \\
\text { gold side effects } \\
\text { (30 cases) }\end{array}$ & $\begin{array}{l}\text { Patients without } \\
\text { side effects } \\
\text { (37 cases) }\end{array}$ & $\chi^{2}$ & $p$ \\
\hline $\begin{array}{c}\text { A1 present } \\
\text { absent }\end{array}$ & $\begin{array}{l}16 \\
14\end{array}$ & $\begin{array}{r}8 \\
29\end{array}$ & $7 \cdot 24$ & $4<10^{-2}$ \\
\hline $\begin{array}{c}\text { B8 present } \\
\text { absent }\end{array}$ & $\begin{array}{l}13 \\
17\end{array}$ & $\begin{array}{r}5 \\
32\end{array}$ & $7 \cdot 49$ & $9<10^{-2}$ \\
\hline $\begin{array}{c}\text { Cw7 present } \\
\text { absent }\end{array}$ & $\begin{array}{r}22 \\
8\end{array}$ & $\begin{array}{l}12 \\
25\end{array}$ & 11.08 & $8<10^{-3}$ \\
\hline $\begin{array}{c}\text { DR3 present } \\
\text { absent }\end{array}$ & $\begin{array}{l}14 \\
16\end{array}$ & $\begin{array}{r}5 \\
32\end{array}$ & 8.96 & $6<10^{-2}$ \\
\hline $\begin{array}{l}\text { DR4 present } \\
\text { absent }\end{array}$ & $\begin{array}{l}17 \\
13\end{array}$ & $\begin{array}{l}25 \\
12\end{array}$ & NS & \\
\hline
\end{tabular}

Table $2 A 1 C w 7 B 8$ DR3 haplotype distribution among 42 RA patients with or without gold side effects

\begin{tabular}{llllll}
\hline Haplotype & $\begin{array}{l}\text { Patients with } \\
\text { gold side effects } \\
(n: 21)\end{array}$ & $\begin{array}{l}\text { Patients without } \\
\text { gold side effects } \\
(n: 21)\end{array}$ & $\chi^{2}$ & $p$ & $R R$ \\
\hline $\begin{array}{l}\text { Present } \\
\text { Absent }\end{array}$ & 12 & 3 & 8.4 & $<10^{-2}$ & 8.0 \\
\hline
\end{tabular}

Table $3 \delta$ Values for some HLA and gold intolerance in $R A$

\begin{tabular}{ll}
\hline Antigens & $\delta^{*}$ \\
\hline A1 & $0 \cdot 23$ \\
B8 & $0 \cdot 19$ \\
Ew7 & $0 \cdot 37$ \\
DR3 & $0 \cdot 21$ \\
\hline "Calculated according to Bengtsson and Thomson formula.
\end{tabular}

D-PENICILLAMINE INTOLERANCE

Among the 29 patients who received D-penicillamine 10 cases of intolerance were recorded: 4 proteinuria, 4 skin eruptions, 2 leucopenia, 1 pemphigus, 1 drug-induced lupus. The number of cases was not sufficient for statistical analysis. However, it is worth noting that 3 out of 4 patients with renal intolerance were of the $\mathrm{Cw} 7 \mathrm{~B} 8$ DR3 haplotype.

\section{Discussion}

It is now well established that there is an association between RA and the HLA system, particularly the DR4 antigen. ${ }^{78}$ In addition it seems that the side effects of certain drugs used in the treatment of RA are also related to the major histocompatibility complex (MHC). Thus a relationship between agranulocytosis caused by levamisole and the B27 antigen has been observed, ${ }^{9}$ and Wooley $e t$ al. have demonstrated an increased incidence of adverse renal reactions related to the use of gold salts and D-penicillamine in patients with B8 and DR3 antigens. ${ }^{1}$ The present study confirms the existence of a significant correlation $\left(\mathrm{p}=10^{-2}\right)$ between adverse reactions to gold and the HLA antigens B8 and DR3, However, whereas Wooley et al. demonstrated a relationship only with respect to renal reactions, we observed the same correlation with other types of intolerance, notably cutaneous reactions. We also found a correlation with 2 other HLA alleles: A1 and $\mathrm{Cw} 7\left(\mathrm{p}=10^{-2}\right)$, The existence of a linkage disequilibrium between these alleles and B8 and DR3 has already been established for the Caucasian population. ${ }^{10}$

The haplotypic study showed that the predisposition to renal reactions to gold salts is associated with the $\mathrm{A} 1 \mathrm{Cw} 7 \mathrm{~B} 8 \mathrm{DR} 3$ haplotype, which has a greater frequency and a stronger linkage disequilibrium in RA. ${ }^{7}$

Our data relating to adverse reactions to D-penicillamine treatment do not permit a clear-cut conclusion to be drawn owing to the limited number of cases available. However, other studies ${ }^{111}$ favour a correlation between renal reactions due to D-penicillamine and the DR3 antigen.

The mechanism governing predisposition to adverse reactions during therapy does not appear to be simple. One could postulate that the gene (or genes) conferring predisposition to gold salt intolerance is situated in the $D$ region. This is not supported by the Bengtsson $\delta$ value, which measures the degree of association between a possible gene for predisposition and the HLA markers, since this shows that the association with DR3 of the B8 DR3 haplotype is weak $(0 \cdot 21)$. The data presented here could rather 
indicate that the postulated gene is situated a long way from the marker gene or more probably that there is a synergistic function of a series of genes in disequilibrium with the HLA markers.

\section{References}

1 Wooley P H, Griffin B J, Panayi G S, Batchelor J R, Welsh K I, Gibson T J. HLA-DR antigens and toxic reaction to sodium aurotiomalate and D-penicillamine in patients with rheumatoid arthritis. $N$ Engl J Med 1980; 303: 300-2.

2 Ropes M W, Bennett G A, Cobbs S, Jacox R, Jessar R A. Revision of diagnostic criteria for rheumatoid arthritis. Bull Rheum Dis 1958; 9: 175-6.

${ }^{3}$ Mittal K K, Mickey M R, Singal D P, Terasaki P I. Refinement of micro droplet lymphocyte cytotoxicity test. Transplantation 1968; 6: 913-27.

4 Legrand L, Dausset J. A second lymphocyte system (Ly-Li). In: Munksgaard, Kissmeyer-Nielson F, ed. Histocompatibility Testing. Copenhagen: 1975, 665-70.
5 Woolf B. On estimating the relation between blood group and disease. Ann Human Genet 1955; 19: 251-3.

- Bengtsson B O, Thomson G. A new measure estimating the strength of associations between HLA antigens and diseases. Ann Hum Genet in press.

7 Dryll A, Bardin T, Debeyre N, et al. Rheumatoid arthritis and HLA complex: a haplotype study in 81 patients. 15th international Congress of Rheumatology. Paris: 1981.

- Stastny P. Association of the B cell alloantigen DRw4 with rheumatoid arthritis. $N$ Engl J Med 1978; 298: 869-71.

- Veys E M, Miclants H, Verbruggen G. Levamisole induced adverse reactions in HLA B27 positive rheumatoid arthritis. Lancet 1978; i: 148.

10 Dausset J, Legrand L, Lepage V, et al. A haplotype study of HLA complex with special reference to the HLA-DR series and to Bf1 C2 and glyoxalase I polymorphisms. Tissue Antigens 1978; 12: 297-307.

1 Smolen J S, Scherax O, Menzel E J, Mayr W R. HLA-A, B, C and DR in rheumatoid arthritis. Presented to histocompatibility workshop, Los Angeles, 1980. 